\title{
Bacterial anticancer weapons: a promising tool to fight cancer
}

\author{
Ananda M Chakrabarty \\ From 16th International Charles Heidelberger Symposium on Cancer Research \\ Coimbra, Portugal. 26-28 September 2010
}

Pseudomonas aeruginosa is an opportunistic extracellular pathogen for debilitated or immuno-compromised patients, capable of forming biofilms on the epithelial surfaces of various tissues in such patients. The biofilm formation allows the pathogen to evade antibiotic therapy or immune attack, ensuring its long term residence and a niche in the body. Any subsequent attack by an internal or external invader such as cancers, viruses or parasites can threaten and cause the resident bacteria to lose their sanctuary. Consequently, $P$. aeruginosa appears to produce protein weapons, such as azurin, that has structural similarity to immunoglobulins and that can preferentially enter to cancer cells and bind many important intracellular or extracellular proteins, including signalling proteins, that are important for cancer growth. Such binding results in the interference of multiple pathways by which cancer cells grow, significantly inhibiting their growth both in vitro and in vivo in live mice. Azurin can also prevent precancerous lesion formation in normal mouse mammary cells, when such cells are exposed to a carcinogen such as 7,12-dimethyl-benz-antracene, thus demonstrating cancer preventive activity, resembling a vaccine. In addition to its anticancer activity, azurin interferes in the growth of viruses such as HIV/AIDS and parasites such as the malarial parasite Plasmodium falciparum or the toxoplasmosis- causing parasite Toxoplasma gondii. Not only azurin, but some of the peptides derived from azurin such as P28, comprising of 28 azurin amino acid residues 50 to 77 , demonstrate entry specificity in cancer cells and significant cytotoxicity including inhibition of angiogenesis. P28 is currently undergoing phase I human clinical trials in the Unites States with early encouraging results. The ability of azurin to

Correspondence: pseudomo@uic.edu

Department of Microbiology \& Immunology, University of Illinois College of Medicine, Chicago, IL, USA interfere in multiple pathways by which cancer cells grow or interfere in the growth of HIV/AIDS virus or malarial, taxoplasmosis parasites distinguishes it from rationally designed anticancer drugs of the pharmaceutical industry which inhibit a single or a limited number of validated targets in the growth progression pathways of the cancer cells. The cancer cells respond to such rationally designed drugs by changing or switching off the target, thereby rapidly becoming drug resistant. It remains to be seen if azurin will demonstrate efficacy in human patients suffering from multiple diverse diseases such as cancers, HIV/AIDS and malaria, and if effective, may exhibit much less susceptibility to resistance development by the disease agents.

Published: 24 September 2010

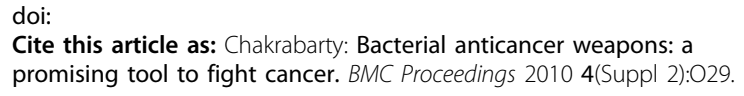

Cite this article as: Chakrabarty: Bacterial anticancer weapons: a promising tool to fight cancer. BMC Proceedings 2010 4(Suppl 2):O29.

Submit your next manuscript to BioMed Central and take full advantage of:

- Convenient online submission

- Thorough peer review

- No space constraints or color figure charges

- Immediate publication on acceptance

- Inclusion in PubMed, CAS, Scopus and Google Scholar

- Research which is freely available for redistribution

Submit your manuscript at www.biomedcentral.com/submit
Biomed Central 